ISSN: $2637-4609$

\title{
Thioglycosides and Cancer Prevention
}

\author{
Anubhuti Sharma*, Ashok Kumar, Arun Kumar, HS Meena, Prashant Yadav, Priti Gupta, Vijaya Laxmi \\ Tripathi, Aadityendra K Sharma and PK Rai
}

ICAR-DRMR, India

Received: 䟧 March 26, 2018; Published: 跙 April 06, 2018

*Corresponding author: Anubhuti Sharma, ICAR-DRMR, Bharatpur, Rajasthan, India, Tel: 09772429768;

Email: sharmaanubhuti98@gmail.com

\begin{abstract}
Plant food contains numerous nutritional \& anti-nutritional compounds, which prevents various non-communicable diseases such as cancer. This paper gives an overview of the cancer preventive effect of brassica. In recent years, considerable attention has been paid to cancer protective role of Brassica through major secondary metabolites i.e. glucosinolates. Glucosinolates and their breakdown products have been widely studied for their biological effect on human and animal nutrition. These are responsible for the secretion of detoxifying enzymes that remove carcinogens from the organism. Furthermore, they activate proteins and II phase detoxifying enzymes. They act as a major defence system to plants and humans. However breakdown products of glucosinolates e.g. isothiocyanate and indole regulates cancer cell development by regulating target enzymes, which are involved in controlling apoptosis and blocking of the cell cycle. The present paper reviews the available literature on glucosinolates, their biosynthesis, hydrolysis, their health promoting beneficial effects and possible role in imparting defence against diseases especially cancer.
\end{abstract}

Keywords: Glucosinolates; Brassica; Isothiocyanates; Phase II enzymes

\section{Introduction}

Rapeseed-mustard group of crops is considered as the oldest cultivated plants in human civilization. It is the third important oilseed crop in the world after soybean (Glycine max) and palm (Elaeis guineensis). Rapeseed-mustard (Brassica spp.) is a common Rabi crop cultivated over 8000 hectare in the sub-Himalayan plains of West Bengal, India. Plants have received considerable attention due to the role of endogenous bioactive compounds in human nutrition [1].

Since 1957, there has been considerable interest in the cancer preventative properties of Brassica plants. This interest has been further strengthened by few epidemiological studies suggesting that sulphur compounds from brassica can reduce gastric juice nitrile concentration and allylic constituent can inhibit HMGCoA reductase to prevent activation of nitrosamines. The cancer preventive properties of crucifers are typically associated with sulphur containing phytochemical compounds, therefore nature of these compounds should be reviewed. Members of cruciferae contain many health promoting and potentially protective phytochemicals including folic acid, phenolics, carotenoids, selenium, organo sulphur compounds and ascorbic acids etc. [2] with anti-proliferative activities. These bioactive compounds provide powerful, broad-spectrum support for protecting against the pervasive cancer provoking agents which enters every day in our environment [3]. The major protective role is due to the presence of a type of bioactive components: glucosinolates.

Glucosinolates are the substituted esters of thio amino acids and methionine and cysteine are the major precursors for their synthesis. Every glucosinolate contains a central carbon atom, which is bound via a sulphur atom to the thioglucose group (making a sulphated aldoxime) and via a nitrogen atom to a sulfate group. In addition, the central carbon is bound to a side group; different glucosinolates have different side groups, and it is variation in the side group that is responsible for the structural \& functional variation of this compounds.

\section{Biosynthesis}

Biosynthesis of glucosinolates comprises three phases: (i) Amino acid chain elongation, in which additional methylene group 
are inserted into the side chain, (ii) conversion of the amino acid moiety to the glucosinolate core structure, (iii) and subsequent side chain modifications.

First, chain elongation of precursor amino acids, in which methionine and other aliphatic amino acids can undergo a process to produce chain elongated homolog of amino acid. This process includes deamination, condensation with acetyl CoA, isomerization and oxidative decarboxylation by an isopropyl malate dehydrogenase (IPM-DH). The result of this series of reactions is addition of a methylene group to the precursor amino acid [4].

The second step involves construction of glucosinolate core structure. The precursor amino acids are converted into aldoximes by cytochromes P450 of the CYP79 family. These aldoximes are oxidized to activated compounds by cytochromes P450 of the CYP83 family. These activated compounds undergo initial conjugation process where cysteine is the sulphur donor. The initial conjugation product is further processed by $\gamma$-glutamyl peptidase (GGP1) to produce cysteine-glycine conjugates i.e. S-alkyl-thiohydroximates [5].The resulting S-alkyl-thiohydroximates are converted to thiohydroximates by the C-S lyase SUR1 [6]. Thiohydroximates are in turn S-glycosylated by glucosyltransferase UGT74B1 to form desulfo-GS (ds-GS). The glycosylation gives rise to dsGS, which are finally sulfated by the sulfotransferases to form complete glucosinolate.

The third process involves side chain modifications of the glucosinolates. The biological activity of GS is influenced by the structure of the side chains [7]. Aliphatic GS can undergo oxygenation, hydroxylation, dehydrogenation, and benzoylation. Indolic GS can undergo hydroxylation and methoxylation.

During the GS synthesis, the prolongation of the carbon chain occurs with natural donors which synthesize homo-methionine amino acid. The natural donors of the thio group are methionine or cysteine amino acids. However this synthesis differs from each other according to the character of the $\mathrm{R}$ side chain of the synthesised glucosinolate. For example Magrath [8] recognised the products 2-amino-6-methyl-thio-hexane and 2-amino-7-methylthio-heptane acids synthesised during biosynthesis as alkenyle glucosinolates. Similarly, indole glucosinolates biosynthesis starts from L-tryptophane, however, in this process chain prolongation does not occur. Here glucose is switched to its activated form by uridine-biphosphate-glucose (UDPG). Then sulphate group is transferred by phosphor adenosine phosphate (PAPS). The biosynthetic pathway of glucosinolates has been almost entirely elucidated in Arabidopsis (Figure 1).

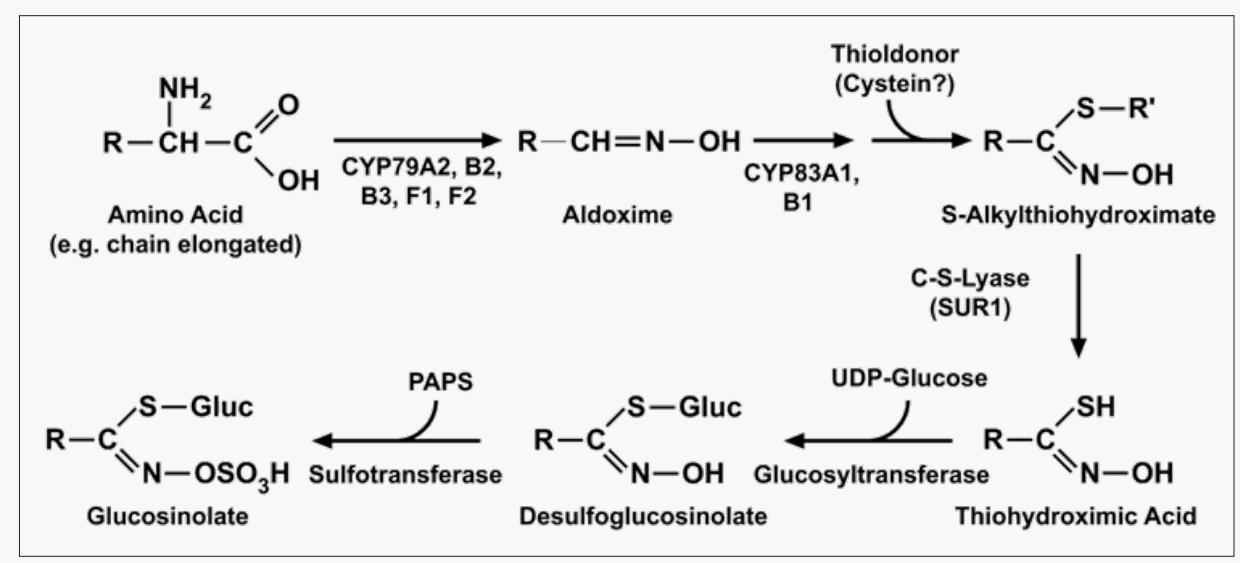

Figure 1: Glucosinolates biosynthesis (GLS are derived from proteinogenic amino acids e.g. alanine, leucine, isoleucine, methionine, phenylalanine, tryptophan, tyrosine and valine, which may undergo one to several rounds of chain elongation (especially methionine) before the glucosinolate core structure is synthesized. Most of the enzymes involved in the core structure biosynthesis have been identified and cloned.

Table 1: Chemical structures of glucosinolates in Brassica species. Trivial name and chemical formula of R side-chains of glucosinolates identified in Brassica species, Mol. Wt. \#: molecular weight of de-sulfo glucosinolates.

\begin{tabular}{|c|c|c|c|c|}
\hline \multirow{2}{*}{ GSL name } & Trivial Name & R-Side Chain & Chemical Structure & Mol Wt. \\
\hline \multirow{5}{*}{ Aliphatic 3C } & Sinigrin & 2-Propenyl & $\mathrm{CH}_{2}=\mathrm{CH}_{-}-\mathrm{CH}_{2}-$ & 279 \\
\cline { 2 - 5 } & Glucoibervirin & 3-Methylthiopropyl & $\mathrm{CH}_{3} \mathrm{~S}-\mathrm{CH}_{2}-\mathrm{CH}_{2}-\mathrm{CH}_{2}-$ & 327 \\
\cline { 2 - 5 } & Glucoiberrin & 3- methylsulfinylpropyl & $\mathrm{CH}_{3} \mathrm{SO}_{-}-\mathrm{CH}_{2}-\mathrm{CH}_{2}-\mathrm{CH}_{2}-$ & 343 \\
\cline { 2 - 5 } & Glucheirolin & 3- methylsulfinylpropyl & $\mathrm{CH}_{3} \mathrm{SO}_{2} \mathrm{CH}_{2}-\mathrm{CH}_{2}-\mathrm{CH}_{2}-$ & 179.26 \\
\cline { 2 - 5 } & Glucoputranjivin & 1-Methylethyl & $\mathrm{CH}_{3}-\mathrm{CH}_{-}-\mathrm{CH}_{3}$ & 281 \\
\cline { 2 - 5 } & Glucosisymbrin & 2-hydroxy-1-methylethyl & $\mathrm{OH}_{2}-\mathrm{CH}_{2}-\mathrm{CH}_{-}-\mathrm{CH}_{3}$ & 298 \\
\hline
\end{tabular}




\begin{tabular}{|c|c|c|c|c|}
\hline \multirow{8}{*}{ Aliphatic 4C } & Gluconapin & 3-butenyl & $\mathrm{CH}_{2}=\mathrm{CH}-\mathrm{CH}_{2}-\mathrm{CH}_{2}-$ & 293 \\
\hline & Progoitrin & (2R)-2-Hydroxy-3-butenyl & $\mathrm{CH}_{3}=\mathrm{CH}-\mathrm{CH}(\mathrm{OH})-\mathrm{CH}_{2}^{-}$ & 309 \\
\hline & Epi-Progoitrin & (2S)-2-Hydroxy-3-butenyl & $\mathrm{CH}_{2}=\mathrm{CH}-\mathrm{CH}(\mathrm{OH})-\mathrm{CH}_{2}^{-}$ & 309 \\
\hline & Glucoerucin & 4-Methylthiobutyl & $\mathrm{CH}_{3} \mathrm{~S}-\mathrm{CH}_{2}-\mathrm{CH}_{2}-\mathrm{CH}_{2}-\mathrm{CH}_{2}-$ & 341 \\
\hline & Glucoraphasatin & 4-Methylthio-3- butenyl & $\mathrm{CH}_{3} \mathrm{~S}-\mathrm{CH}=\mathrm{CH}-\mathrm{CH}_{2}-\mathrm{CH}_{2}-$ & 340 \\
\hline & Glucoraphanin & 4-Methylsulfinyl butyl & $\mathrm{CH}_{3} \mathrm{SO}-\mathrm{CH}_{2}-\left(\mathrm{CH}_{2}\right)_{2}-\mathrm{CH}_{2}-$ & 357 \\
\hline & Glucoraphenin & 4-Methylsulfinyl-3- butenyl & $\mathrm{CH}_{3} \mathrm{SO}-\mathrm{CH}=\mathrm{CH}-\mathrm{CH}_{2}-\mathrm{CH}_{2}-$ & 355 \\
\hline & Glucoconringin & 2-Hydroxy-2-methylpropyl & $\mathrm{CH}_{3}=\mathrm{CH}(\mathrm{OH})-\mathrm{CH}_{2}^{-}$ & 312 \\
\hline \multirow{5}{*}{ Aliphatic 5C } & Glucoalyssin & 5-Methylsulfinylpentyl & $\begin{array}{c}\mathrm{CH}_{3} \mathrm{SO}-\mathrm{CH}_{2}-\mathrm{CH}_{2}-\mathrm{CH}_{2}-\mathrm{CH}_{2}- \\
\mathrm{CH}_{2}^{-}\end{array}$ & 371 \\
\hline & Glucobrassicanapin & Pent-4-enyl & $\mathrm{CH}_{2}=\mathrm{CH}-\mathrm{CH}_{2}-\mathrm{CH}_{2}-\mathrm{CH}_{2}-$ & 307 \\
\hline & Glucoberteroin & 5-Methylthiopentyl & $\begin{array}{c}\mathrm{CH}_{3} \mathrm{~S}-\mathrm{CH}_{2}-\mathrm{CH}_{2}-\mathrm{CH}_{2}-\mathrm{CH}_{2}^{-} \\
\mathrm{CH}_{2}^{-}\end{array}$ & 354 \\
\hline & Gluconapoleiferin & 2-Hydroxy-Pent-4-enyl & $\mathrm{CH}_{2}=\mathrm{CH}-\mathrm{CH}_{2}-\mathrm{CH}-\mathrm{OH}-\mathrm{CH}_{2}^{-}$ & 323 \\
\hline & Glucocleomin & 2-Hydroxy-2-methylbutyl & $\mathrm{CH}_{3}-\mathrm{CH}_{2}-\mathrm{CH}(\mathrm{OH})-\mathrm{CH}_{2}-\mathrm{CH}_{2}-$ & 326 \\
\hline \multirow{2}{*}{ Aliphatic 6C } & Glucolesquerellin & 6-Methylthiohexyl & $\begin{array}{c}\mathrm{CH}_{3} \mathrm{~S}-\mathrm{CH}_{2}-\mathrm{CH}_{2}-\mathrm{CH}_{2}-\mathrm{CH}_{2}- \\
\left(\mathrm{CH}_{2}\right)_{2}^{-}\end{array}$ & 370 \\
\hline & Glucohesperin & 6-Methylsulfinylhexyl & $\begin{array}{c}\mathrm{CH}_{3} \mathrm{SO}-\mathrm{CH}_{2}-\mathrm{CH}_{2}-\mathrm{CH}_{2}-\mathrm{CH}_{2}^{-} \\
\left(\mathrm{CH}_{2}\right)_{2}^{-}-\end{array}$ & 385 \\
\hline \multirow{2}{*}{ Aliphatic 7C } & Glucoarabishirsutain & 7-Methylthioheptyl & $\begin{array}{c}\mathrm{CH}_{3} \mathrm{~S}-\mathrm{CH}_{2}-\mathrm{CH}_{2}-\mathrm{CH}_{2}-\mathrm{CH}_{2}- \\
\left(\mathrm{CH}_{2}\right)_{3}-\end{array}$ & 384 \\
\hline & Glucoibarin & 7-Methylsulfinylheptyl & $\begin{array}{c}\mathrm{CH}_{3} \mathrm{SO}-\mathrm{CH}_{2}-\mathrm{CH}_{2}-\mathrm{CH}_{2}-\mathrm{CH}_{2}- \\
\left(\mathrm{CH}_{2}\right)_{3}^{-}\end{array}$ & 399 \\
\hline \multirow{2}{*}{ Aliphatic 8C } & Glucoarabishirsuin & 8-Methylthiooctyl & $\begin{array}{c}\mathrm{CH}_{3} \mathrm{~S}-\mathrm{CH}_{2}-\mathrm{CH}_{2}-\mathrm{CH}_{2}-\mathrm{CH}_{2}^{-} \\
\left(\mathrm{CH}_{2}\right)_{4}^{-}\end{array}$ & 398 \\
\hline & Glucohirsutin & 8-Methylsulfinyloctyl & $\begin{array}{c}\mathrm{CH}_{3} \mathrm{SO}-\mathrm{CH}_{2}-\mathrm{CH}_{2}-\mathrm{CH}_{2}-\mathrm{CH}_{2}^{-} \\
\left(\mathrm{CH}_{2}\right)_{4}^{-}-\end{array}$ & 414 \\
\hline \multirow{4}{*}{ Indole } & Glucobrassicin & 3-Indolylmethyl & $\mathrm{C}_{16} \mathrm{H}_{19} \mathrm{~N}_{2} \mathrm{O}_{9} \mathrm{~S}_{2}^{-}$ & 368 \\
\hline & 4-Hydroxyglucobrassicin & 4-Hydroxy-3-indolylmethyl & $\mathrm{C}_{16} \mathrm{H}_{19} \mathrm{~N}_{2} \mathrm{O}_{9} \mathrm{~S}_{2}^{-}$ & 384 \\
\hline & 4-Methoxyglucobrassicin & 4-Methoxy-3-indolylmethyl & $\mathrm{C}_{17} \mathrm{H}_{22} \mathrm{~N}_{2} \mathrm{O}_{10} \mathrm{~S}_{2}^{-}$ & 398 \\
\hline & Neoglucobrassicin & N-Methoxy-3-indolylmethyl & $\mathrm{C}_{17} \mathrm{H}_{22} \mathrm{~N}_{2} \mathrm{O}_{10} \mathrm{~S}_{2}^{-}$ & 398 \\
\hline \multirow{5}{*}{ Aromatic } & Glucotropacolin & Benzyl & $\mathrm{C}_{14} \mathrm{H}_{18} \mathrm{NO}_{9} \mathrm{~S}_{2}-$ & 329 \\
\hline & Glucosinalbin & p-Hydroxybenzyl & $\mathrm{C}_{14} \mathrm{H}_{19} \mathrm{NO}_{10} \mathrm{~S}_{2}-$ & 345 \\
\hline & Gluconasturtiin & 2-Phenethyl & $\mathrm{C}_{15} \mathrm{H}_{21} \mathrm{NO}_{9} \mathrm{~S}_{2}^{-}$ & 343 \\
\hline & Glucobarbarin & $\begin{array}{l}\text { (2S)-2-Hydroxy-2- } \\
\text { phenethyl }\end{array}$ & $\mathrm{C}_{15} \mathrm{H}_{20} \mathrm{NO}_{10} \mathrm{~S}_{2} \cdot \mathrm{K}$ & 360 \\
\hline & Glucomalcomin & 3-Benzoyloxypropyl & $\mathrm{C}_{6} \mathrm{H}_{5} \mathrm{COO}\left(\mathrm{CH}_{2}\right)_{4}$ & 402 \\
\hline
\end{tabular}

\section{Diversity}

Till date nearly 200 Glucosinolates types have been identified (Table 1), which are classified into three classes based on the structure of different amino acid precursors: aliphatic, indole, and aromatic [9]. However, glucosinolates of each group are synthesized through an independent metabolic pathway with the help of a common set of enzymes involved in the formation of different glucosinolates under genetic control [10]. Similarly, it has been noticed [11] that glucosinolates compositions \& its content are mainly affected by the genotype, climate and cultivation conditions including fertilization, harvest time and plant position. Number of environmental conditions such as light, nutritional status, fungal infection, wounding and insect damage etc. can alter the glucosinolate pattern significantly.

Reichelt M $[12,13]$ reported 34 different types of glucosinolates in the leaves of different ecotypes in Arabidopsis. Similarly, Padilla [14] reported 16 different glucosinolates among 116 accessions of turnip greens and He [15] studied 8 different glucosinolates with gluconapin and gluco brassica napin as predominant aliphatic glucosinolates. Furthermore, variation in concentration of individual glucosinolates also exists in cultivars of the same species. These products have a wide range of biological activity, which include both positive and negative nutritional attributes and effects on the attraction, growth, and survival of plant-herbivores [16]. 


\section{Hydrolysis}

Plants with glucosinolate activity always possess myrosinase (a thioglucoside glucohydrolase), which are involved mainly in the hydrolysis of the glucose moiety on the main skeleton and results into the formation of unstable aglycone and glucose. These two further rearrange to form isothiocyanate, nitriles and other products (Figure 2). These hydrolytic products contribute towards the different biological activities of the glucosinolates [17].

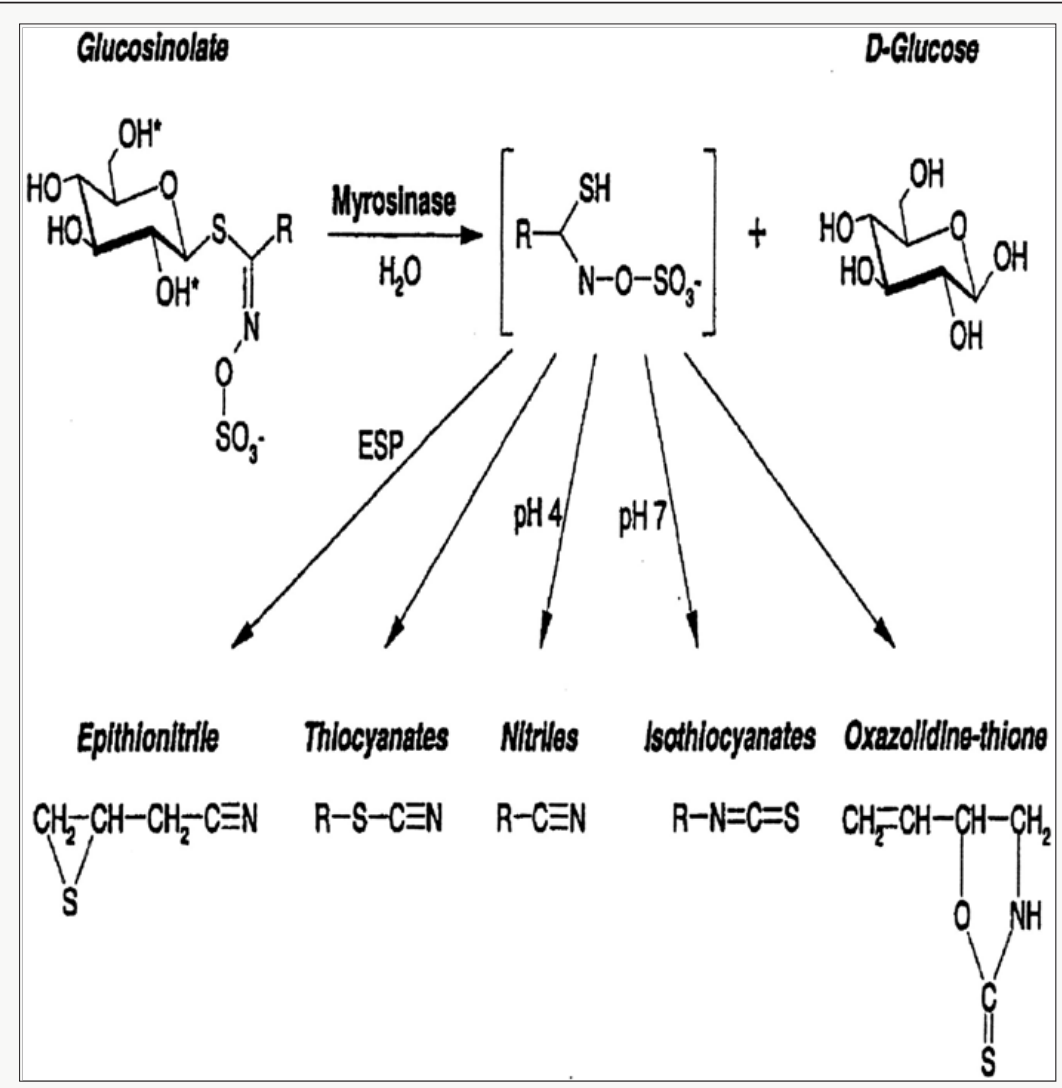

Figure 2: Glucosinolates and their possible products after myrosinase cleavage at different pH.R denotes amino acid-derived side chains. Epithio specifier protein (ESP) together with the $\mathrm{pH}$ and other factors are critical parameters determining which product is formed from the aglucone. (Source: www.plantphysiol.org).

These hydrolytic products vary from plant to plant and it is dependent on original patterns of glucosinolates, environmental factors such as $\mathrm{pH}$, presence of ferrous ions etc. In addition epithio specific protein (ESP) determines the metabolic conversion of glucosinolates e.g. in the presence of ESP glucosinolates converts into epithionitriles whereas in the absence of ESP glucosinolates converts into isothiocyanates [9].

Glucosinolates are mainly located in the parenchymatous tissues, mainly in vacuoles together with ascorbic acid whereas myrosinase enzyme is separately localised into the idioblast cells [18]. Therefore damage to these tissues, both by grinding, digestion, mechanical injury and damage by insects leads to selfhydrolysis and synthesis of its biosynthetic products. It has been mentioned earlier that ascorbic acid is able to modulate myrosinase activity i.e. inhibition at higher concentration and activation at lower concentration [19]. In the era of natural product research, glucosinolates and their breakdown products are of particular interest because of their proposed anti-carcinogenic properties.

\section{Examples}

Approximately 120 classes of glucosinolates have been identified in plants; however each plant species contains any three to four glucosinolates in significant amount [20]. Glucoiberrin, progoitrin, sinigrin, glucoraphanin, glucoerucin, gluconapoleiferin, glucobrassicin, sinalbin are few important glucosinolates found in order brassicales (table 1). Sinigrin and sinalbin are two major glycosides occurring in mustard seeds. These glucosinolates were isolated early in the 1830s from black (Brassica nigra) and white (Sinapis Alba) mustard seeds, respectively. Sinalbin (SNB) is the major glucosinolate found in yellow mustard (Sinapis Alba) [21]. The hydrolysis of sinigrin gives a glucose, allyl isothiocyanate (volatile oil of mustard) and potassium acid sulphate, whereas the hydrolysis of sinalbin gives a phenolic isothiocyanate, glucose and sinapine. Pungency and bitterness are the major quality factors for brassica species which is mainly caused by the glucosinolate breakdown. Although these compounds contribute taste \& odour to condiments, these may also exhibit goitrogenic or anti-thyroid 
activity [22]. (If consumed in high quantity). Glucosinolates are also known for their anti-cancerous properties [20].

\section{Sources}

The species in which glucosinolates occur that are important for animal or human feeding belong to the family Brassicaceae (e.g. Cruciferae, Capparidaceae, and Caricaceae), but also in the genus Drypetes (family Euphorbiaceae) [23]. Major sources for glucosinolates include: rapeseed, cabbage, cauliflower, Brussels sprouts, swede/turnip, calabrese/ broccoli and Chinese cabbage, radishes, mustard seed and horse radish. However McNaughton and Marks, [24] (2003) reported higher levels (> 100mg/100g fresh weight) in Brussels sprouts, cress and mustard greens.

\section{Anti-nutritional effect}

Glucosinolates and some of their metabolites have been shown to be mutagenic and weakly Genotoxic [25]. The most remarkable degradation product is oxazolidine-2-thione, which is derived from progoitrin [26]. They also reported that this glucosinolate causes gioter and other harmful effects on animal nutrition, such as depressed growth, poor egg production and liver damage.

\section{Anti-cancer effects in humans}

It is the biotransformation enzymes that play important roles in the metabolism and elimination of a variety of chemicals e.g. toxins released after metabolic activities and carcinogens. These biotransformation enzymes includes mainly phase I metabolizing enzymes that catalyzes reactions to increase the reactivity of hydrophobic (fat-soluble) compounds, and Phase II enzymes involved primarily into catalysis of conjugation reactions. It has been shown earlier that reactions catalyzed by phase II enzymes generally increase water solubility and promote the elimination of the compound from the body [27].

Fahey [20] reported that glucosinolate degradation products, especially isothiocyanates have been involved in anti-carcinogenic properties. They identified glucosinolates as $\beta$-thioglucoside $\mathrm{N}$-hydroxysulfates with more than 120 unique amino acid side chains. It has been reported that glucosinolates are not only anticarcinogenic but can act as potential antioxidant [9] and protects against herbivores and microbes [28]. ITCs occur primarily in cruciferous vegetables, many of which show significant cancer chemo-preventive activities, and therefore are widely suspected to account in part for the cancer preventive activities of these vegetables in humans. Sulforaphane is perhaps the most widely known crucifer-derived cancer chemo-preventive ITC [29].

Mechanisms of anti-carcinogenic action of sulforaphane involves the direct detoxication of carcinogens followed by inhibition of phase 1 enzymes of the cytochrome P450 system, thereby prevents formation of carcinogen-induced DNA-adducts, formed by heterocyclic amines [30]. This leads to the indirect involvement of sulforaphane in elimination of reactive anti- oxidants (ROS) and further improves the antioxidative cellular activity. However, sulforaphane acts by other mechanisms too. It induces cell cycle arrest, apoptosis in cancer cells, and sometimes inhibition of histone deacetylase also [31]. In addition it has been reported to inhibit nuclear factor- jB (NF-jB) activity and affects the expression of NF-jB mediated genes encoding adhesion molecules, inflammatory cytokines, growth factors and anti-apoptotic factors [32].

Lawson [33] reported that a number of glucosinolate hydrolytic product i.e. isothiocyanates (e.g. phenethylisothiocyanate (PEITC), benzyl isothiocyanate (BITC) and sulforaphane) induces cell cycle arrest in cultured cells. These isothiocyanates can also modify the balance of Phase I and II xenobiotic metabolizing enzymes. This protective effect may be due to improved phytochemicals with antioxidant status. Phase II enzymes such as the glutathione transferase family (GST) plays a major role in the detoxification of different types of mutagens. Lam [34] described that individuals with homozygous deletion for GSTM1 and GSTM2 had strongest reciprocal relationship of total cruciferous vegetable intake with lung cancer risk.

\section{Conclusion}

Glucosinolates is a major natural product of brassicacae family with a large group of bioactive compounds. These compounds are mainly non toxic and exhibits broad bioactivities e.g. defense system of the plant, antitumor activity in human etc. In earlier days research was focussed mainly on lowering of glucosinolates in the cultivars because of their contribution to characteristic property of bitterness in the seed meal/oilcake. However their immense advantages in agriculture have inspired the plant breeders to raise varieties with increased glucosinolates.

Apart from their defense response in plants, glucosinolates can also perform as chemopreventive agents. However their tumerogenic ability depends mainly on structure of the glucosinolates, hydrolytic products, target tissues, the animal species and the specific carcinogen used. They can act either by arresting cell cycle progression or preventing growth of cancer cells i.e. apoptosis etc. This review provides valuable information for developing new cultivars with an appropriate glucosinolate profile, which can be used to develop high quality value added products used in agriculture and medicine. However there is a prerequisite to further explore, characterise and commercialize the glucosinolates in humans to design future chemoprotection studies.

Investigations on hydrolytic products of glucosinolates (mainly allyl isothiocyanates) and other nutritional phytochemicals in Indian mustard are currently in progress in our group.

\section{Acknowledgement}

The authors gratefully acknowledge the necessary facilities extended by ICAR-DRMR, Bharatpur for carrying out the study. 


\section{References}

1. Sharma A, Sharma AK, Yadav P, Singh D (2016) Isothiocyanates in Brassica: A potential anticancer agent. Asian Pacific Journal of cancer prevention 17(9): 4507-4510.

2. Martínez Ballesta M, Moreno Fernández DA, Castejón D, Ochando C, Morandini PA, et al. (2015) The impact of the absence of aliphatic glucosinolates on water transport under salt stress in Arabidopsis thaliana. Frontiers in plant science 6: 524.

3. Sharma A, Kumar A, Meena HS, Singh D (2017) Chromatographic determination of phenolics in Brassica juncea. Asian Journal of Chemistry 29: 296-300.

4. Sonderby IE, Geu Flores F, Halkier BA, (2010) Biosynthesis of glucosinolates-gene discovery and beyond. Trends in Plant Science 15(5): 283-290.

5. Geu-Flores F, Moldrup ME, Bottcher C Olsen CE, Scheel D, et al. (2011) Cytosolic-glutamyl peptidases process glutathione conjugates in the biosynthesis of glucosinolates and camalexin in Arabidopsis. Plant Cell 23(6): 2456-2469.

6. Mikkelsen RL, Middelboe T, Pisinger C (2004) Anxiety and depression in patients with chronic obstructive pulmonary disease (COPD). A review. Nordic Journal of Psychiatry 58(1): 65-70.

7. Stotz HU, Sawada Y, Shimada Y, Hirani MY, Sasaki E, et al. (2011) Role of camalexin indole glucosinilates, and side chain modification of glucosinolate-drived isothiocynates in defence of arabdopsis against sclerotinia sclerotinum. Plant journal 67(1): 81-93.

8. Magrath R, Bano F, Morgner M, I Parkin, A Sharpe, et al. (1994) Genetics of aliphatic glucosinolates. I. Side chain elongation in Brassica napus and Arabidopsis thaliana. Heredity 72: 290-299.

9. Halkier BA, Gershenzon J (2006) Biology and biochemistry of glucosinolates. Annual Review of Plant Biology 57: 303-333.

10. Hirani AH, Li G, Zelmer CD, Aakash Goyal, M Asif, et al. (2012) Molecular genetics of glucosinolate biosynthesis in Brassicas: Genetic manipulation and application aspects.

11. Verkerk R, Schreiner M, Holst B, Rowland I, De Schrijver R, et al. (2009) Glucosinolates from Brassica vegetables; The influence of the food supply chain on intake, bioavailability and human health. Molecular Nutrition and Food Research.

12. Brown PD, Tokuhisa JG, Reichelt M, Gershenzon J (2003) Variation of glucosinolate accumulation among different organs and developmental stages of Arabidopsis thaliana. Phytochemistry 62: 471-481.

13. Reichelt M, Brown PD, Scheneider B, Oldham NJ, Stauber E, et al. (2002) Benzoic acid glucosinolate esters and other glucosinolates from Arabidopsis thaliana. Phytochemistry 59: 663-671.

14. Padilla G, Cartea ME, Velasco P, de Haro A, Ordás A (2007) Variation of glucosinolates in vegetable crops of Brassica rapa. Phytochemistry 68: 536-545.

15. He Y, Mawhinney TP, Preuss ML, Schroeder AC, Chen B, et al. (2009) A redox-active isopropyl malate dehydrogenase functions in the biosynthesis of glucosinolates and leucine in Arabidopsis. The Plant Journal 60: 679-690.

16. Cartea ME, Velasco P (2008) Glucosinolates in Brassica foods: Bioavailability in food and significance for human health. Phytochemistry Reviews 7: 213-229.
17. Sharma A, Sood S, Agrawal PK, A Pattanayak, JC Bhatt (2016) Detection and Assessment of nutraceuticals in methanolic extract of Finger (Eleusine coracana) and Barnyard millet (Echinochloa frumentacea). Asian Journal of Chemistry 28(7): 1633-1637.

18. Zukalova H, Vasak J (2002) The Role and effects of glucosinolates of Brassica species- a review. Rostlinna Vyroba 48(4): 175-180.

19. Barba Francisco J, Nikmaram Nooshin, Roohinejad Shahin, Khelfa Anissa Zhu Zhenzhou, et al. (2016) Bioavailability of Glucosinolates and Their Breakdown Products: Impact of Processing. Frontiers in Nutrition 3: 24.

20. Fahey JW, Zalcmann AT, Talalay P (2001) The chemical diversity and distribution of glucosinolates and isothiocyanates among plants. Phytochemistry 56: 5-51.

21. Herzallah S, Holley, R (2012) Determination of sinigrin, sinalbin, allyland benzyl isothiocyanates by RP-HPLC in mustard powder extracts. LWT-Food Science and Technology 47: 293-299.

22. Mishra S, Manchanda SC 2012. Cooking oils for heart health. J Preventive cardiology 1(3): 123-131.

23. Liu S, Liu Y, Yang, X, Tong C, Edwards D, et al. (2014) The Brassica oleracea genome reveals the asymmetrical evolution of polyploid genomes. Nature Communications 5: 3930.

24. McNaughton SA, Marks GC (2003) Development of a food composition database for the estimation of dietary intakes of glucosinolates, the biologically active constituents of cruciferous vegetables. British Journal of Nutrition 90: 687-697.

25. Conaway CC, Yang YM, Chung FL (2002) Isothiocyanates as cancer chemopreventive agents: their biological activities and metabolism in rodents and humans. Current Drug Metabolism 3(3): 233-55.

26. Tripathi MK, Mishra AS (2007) Glucosinolates in animal nutrition: A review. Animal Feed Science and Technology 132: 1-27.

27. Lampe JW, Peterson S (2002) Brassica, Bio-transformation and cancer risk: genetic polymorphisms alter the preventive effects of cruciferous vegetables. The Journal of Nutrition 132(10): 2991-2994.

28. Kusznierewicz BS, Miechowska A, Bartoszek A, Namies'nik J (2008) The effect of heating and fermenting on antioxidant properties of white cabbage. Food Chemistry 108(3): 853-861.

29. Zhang Y, Tang L (2007) Discovery and development of sulforaphane as a cancer chemo-preventive phytochemical. Acta Pharmacologica Sinica 28(9): 1343-1354.

30. Shishu, Kaur IP (2003) Inhibition of mutagenicity of food-derived heterocyclic amines by sulphoraphene-an isothiocyanate isolated from radish. Planta Medica 69: 184-186.

31. Clarke JD, Dashwood RH, Ho E (2008) Multi-targeted prevention of cancer by sulforaphane. Cancer Letters 269(2): 291-304.

32. Herr A, McKenzie L, Suryadinata R, Sadowski M, Parsons LM, et al. (2010) Geminin and Brahma act antagonistically to regulate EGFR-RasMAPK signaling in Drosophila. Devlopmental Biology 344(1): 36-51.

33. Lawson AP, Marcus JC Long, Coffey RT, Yu Q, Weerapana E, et al. (2015) Naturally occurring isothiocyanates exert anticancer effects by inhibiting deubiquitinating enzymes. Cancer Ressearch 75(23): 5130-5142.

34. Lam TK, Gallicchio L, Lindsley K (2009) Cruciferous vegetable consumption and lung cancer risk: a systematic review. Cancer Epidemiology Biomarkers \& Prevention 18(1): 184-95. 
(C) (1) This work is licensed under Creative

To Submit Your Article Click Here: Submit Article

DOI: 10.32474/AOICS.2018.02.000141

\section{AOICS}

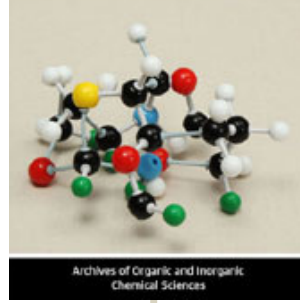

Archives of Organic and Inorganic Chemical Sciences

Assets of Publishing with us

- Global archiving of articles

- Immediate, unrestricted online access

- Rigorous Peer Review Process

- Authors Retain Copyrights

- Unique DOI for all articles 